\title{
PELAKSANAAN KEWENANGAN ATRIBUSI PEMERINTAHAN DAERAH BERDASARKAN UNDANG-UNDANG NOMOR 23 TAHUN 2014 TENTANG PEMERINTAHAN DAERAH
}

\author{
ALI MARWAN HSB \& EVLYN MARTHA JULIANTHY \\ Kantor Wilayah Kementerian Hukum dan HAM Sumatera Utara \\ J1. Putri Hijau Nomor 4 Medan \\ E-mail: ali.marwan13@gmail.com
}

\begin{abstract}
Abstrack
In the practice of the implementation of regional autonomy in Indonesia, the Regional Government has the authority to regulate its own territory by the division of authority as regulated in Act No. 23 of 2014 on Local Government. These powers are matters related to concurrent matters comprising compulsory and optional matters. The question is in the form of a legal product whether local governance regulates these authorities. Based on the search of various provisions of the legislation it can be concluded that the regulation on the exercise of the authority of attribution is to be by local regulations. This is directly related to the content of regional regulatory content, one of which is in the context of regional autonomy. In this regard, it is suggested that in relation to the exercise of the authority of attribution or concurrent affairs of local government shall be governed by regional regulations.
\end{abstract}

Keyword: Authority, Atribution, Local Government.

\begin{abstract}
Abstrak
Dalam praktek pelaksanaan otonomi daerah di Indonesia, Pemerintahan Daerah mempunyai kewenangan untuk mengatur sendiri daerahnya dengan adanya pembagian kewenangan yang diatur dalam Undang-Undang Nomor 23 Tahun 2014 tentang Pemerintahan Daerah. Kewenangan tersebut adalah urusan-urusan yang terkait dengan urusan konkuren yang terdiri dari urusan wajib dan pilihan. Menjadi pertanyaan adalah dalam bentuk produk hukum apakah pemerintahan daerah mengatur kewenangan-kewenangan tersebut. Berdasarkan penelusuran dari berbagai ketentuan peraturan perundang-undangan dapat disimpulkan bahwa pengaturan mengenai pelaksanaan kewenangan atribusi adalah harus dengan peraturan daerah. Hal ini terkait langsung dengan materi muatan peraturan daerah yang salah satunya adalah dalam rangka penyelenggaraan otonomi daerah. Berkaitan dengan itu, maka disarankan agar berkaitan dengan pelaksanaan kewenangan atribusi atau urusan konkuren pemerintahan daerah diatur dengan peraturan daerah.
\end{abstract}

Kata Kunci: Kewenangan, Atribusi, Pemerintahan Daerah.

\section{A. Pendahuluan}

Pembagian kekuasaan secara vertikal di negara kesatuan membawa konsekuensi hadirnya lingkungan pemerintahan pusat (central government) dan lingkungan pemerintahan daerah (local government). Victor M. Situmorang mengungkapkan beberapa alasan dianutnya pembagian kekuasaan secara vertikal sehingga dibentuk sebuah lingkungan pemerintahan daerah, yaitu: ${ }^{1}$

a. Kemampuan Pemerintah berikut perangkatnya yang ada di daerah terbatas;

b. Wilayah negara sangat luas, terdiri dari 3000 pulau besar dan kecil;

c. Pemerintah tidak mungkin mengetahui seluruh dan segala macam kepentingan dan kebutuhan rakyat yang tersebar di seluruh pelosok negara;

d. Hanya rakyat setempatlah yang mengetahui kebutuhan, kepentingan dan masalah yang dihadapi

1 Victor M. Situmorang, Hukum Administrasi Pemerintahan di Daerah, Jakarta: Sinar Grafika, 1994, hlm. 33. 
dan hanya mereka yang mengetahui bagaimana cara yang sebaik-baiknya untuk memenuhi kebutuhan tersebut;

e. Dilihat dari segi hukum, Undang-Undang Dasar 1945 Pasal 18 menjamin adanya daerah dan wilayah;

f. Adanya sejumlah urusan pemerintahan yang bersifat kedaerahan dan memang lebih berdaya guna jika dilaksanakan oleh daerah;

g. Daerah mempunyai kemampuan dan perangkat yang cukup memadai untuk menyelenggarakan urusan rumah tangganya, maka desentralisasi dilaksanakan dalam penyelenggaraan pemerintahan di daerah.

Dengan hadirnya lingkungan pemerintahan pusat dan lingkungan pemerintahan daerah, maka akan menimbulkan konsekuensi logis lainnya, yaitu adanya hubungan antara pusat dan daerah untuk menghindari terjadi tumpang tindih pelaksanaan kewenangan. Dalam konteks Indonesia, hubungan pusat dan daerah mempunyai 4 (empat) asas pokok yang perlu dijadikan pedoman berdasarkan UndangUndang Dasar Negara Republik Indonesia Tahun 1945, yaitu: ${ }^{2}$

a. Bentuk hubungan antara pusat dan daerah tidak boleh mengurangi hak-hak rakyat daerah untuk turut serta dalam penyelenggaraan pemerintahan daerah;

b. Bentuk hubungan antara pusat dan daerah tidak boleh mengurangi hak-hak rakyat daerah untuk berinisiatif dan berprakarsa mengatur dan mengurus urusan-urusan yang dianggap penting bagi daerah;

c. Bentuk hubungan pusat dan daerah dapat berbeda-beda antara daerah yang satu dengan daerah yang lain sesuai dengan keadaan khusus masing-masing daerah;

d. Bentuk hubungan antara pusat dan daerah adalah dalam rangka mewujudkan keadilan dan kesejahteraan sosial di daerah.
Berkenaan dengan tatanan hubungan pemerintah pusat dengan pemerintah daerah, Bagir Manan mengemukakan 3 (tiga) sistem otonomi daerah atau sistem rumah tangga daerah, yaitu: ${ }^{3}$

1. Sistem rumah tangga formal, di mana pembagian wewenang, tugas dan tanggung jawab antara pusat dan daerah untuk mengatur dan mengurus urusan pemerintahan tertentu tidak ditetapkan secara rinci;

2. Sistem rumah tangga material, ada pembagian wewenang, tugas dan tanggung jawab yang rinci antara pusat dan daerah;

3. Sistem rumah tanggal nyata atau riil, pembagian wewenang, tugas dan tanggung jawab kepada daerah didasarkan pada keadaan dan faktor-faktor nyata/riil yang memungkinkan daerah menyelenggarakan urusan pemerintahan.

Selain itu, akibat dari dianutnya sistem otonomi daerah adalah berkaitan dengan hubungan kewenangan antara pusat dan daerah. Hubungan kewenangan antara lain bertalian dengan cara menentukan urusan rumah tangga daerah. ${ }^{4}$ Dalam melaksanakan otonomi daerah dan tugas pembantuan berdasarkan Pasal 18 Ayat (6) Undang-Undang Dasar Negara Republik Indonesia Tahun 1945, pemerintah daerah berhak membentuk peraturan daerah dan peraturan lain. Hal ini lah yang menjadi pertanyaan dalam bentuk produk hukum apakah pemerintahan daerah mengatur tentang pelaksanaan urusan pemerintahan daerah tersebut. Apakah dalam peraturan daerah atau peraturan kepala daerah?

\section{B. Pembahasan}

\section{B.1.Sumber Kewenangan Pemerintah Daerah}

Kewenangan memiliki kedudukan penting dalam kajian hukum tata negara dan hukum administrasi. Begitu pentingnya kedudukan kewenangan ini sehingga F.A.M Stroink dan J.G. Steenbek menyebutnya sebagai konsep inti dalam hukum tata negara dan hukum administrasi. ${ }^{5}$ Dalam literatur

2 Nukhtoh Arfawie Kurde, Peranan Desentralisasi dan Otonomi Daerah dalam Penguatan Integrasi Negara Kesatuan Republik Indonesia, Yogyakarta, Program Pasca Sarjana FH UII, 2006, hlm. 143.

3 Bagir Manan, Hubungan antara Pusat dan Daerah Menurut UUD 1945, Jakarta: Pustaka Sinar Harapan, 1994, hlm. $26-32$.

$4 \quad$ Ni'matul Huda, Hukum Pemerintahan Daerah, Jakarta: Nusamedia, 2009, hlm. 15.

5 Ridwan HR, Hukum Administrasi Negara, Jakarta: Rajawali Pers, 2006, hlm. 101. 
hukum administrasi dijelaskan, bahwa istilah wewenang seringkali disepadankan dengan istilah kekuasaan. Padahal, istilah kekuasaan tidaklah identik dengan istilah wewenang. ${ }^{6}$

Menurut P. Nicolai sebagaimana dikutip Aminuddin Ilmar, wewenang pemerintahan adalah kemampuan untuk melakukan tindakan atau perbuatan hukum tertentu, yakni tindakan atau perbuatan yang dimaksudkan untuk menimbulkan akibat hukum dan mencakup mengenai timbul dan lenyapnya akibat hukum. Selanjutnya, dikemukakan juga bahwa dalam wewenang pemerintah itu tersimpul adanya hak dan kewajiban dari pemerintah dalam melakukan tindakan atau perbuatan pemerintahan tersebut. ${ }^{7}$

Mengenai wewenang ini, H.D. Stout mengatakan bahwa wewenang merupakan pengertian yang berasal dari hukum organisasi pemerintahan, yang dapat dijelaskan sebagai keseluruhan aturan-aturan yang berkenaan dengan perolehan dan penggunaan wewenang pemerintahan oleh subjek hukum publik di dalam hubungan hukum publik. ${ }^{8}$ Sedangkan menurut F.P.C.L. Tonnaer, kewenangan pemerintah dalam kaitan ini dianggap sebagai kemampuan untuk melaksanakan hukum positif, dan dengan begitu, dapat diciptakan hubungan hukum antara pemerintah dengan warga negara. ${ }^{9}$

Selain itu, menurut S.F. Marbun, wewenang mengandung arti kemampuan untuk melakukan suatu tindakan hukum publik, atau secara yuridis adalah kemampuan bertindak yang diberikan oleh undang-undang yang berlaku untuk melakukan hubungan-hubungan hukum. Dengan demikian, wewenang pemerintahan memiliki sifat-sifat antara lain: (1) express implied, (2) jelas maksud dan tujuannya, (3) terikat pada waktu tertentu, (4) tunduk pada batasan-batasan hukum tertulis dan tidak tertulis dan (5) isi wewenang dapat bersifat umum dan konkrit. ${ }^{10}$
Menurut Henc van Maarseveen, di dalam hukum publik, wewenang sekurang-kurangnya terdiri dari 3 (tiga) komponen, yaitu: ${ }^{11}$

1. Komponen pengaruh, ialah bahwa penggunaan wewenang dimaksudkan untuk mengendalikan perilaku subjek hukum;

2. Komponen dasar hukum, bahwa wewenang itu selalu harus dapat ditunjuk dasar hukumnya; dan

3. Komponen konformitas hukum, mengandung makna adanya standard wewenang, baik standard umum maupun standard khusus.

Pada dasarnya wewenang pemerintah itu, menurut Prajudi Atmosudirdjo, dapat dijabarkan ke dalam 2 (dua) pengertian, yakni sebagai hak untuk menjalankan suatu urusan pemerintahan dan sebagai hak untuk dapat secara nyata memengaruhi keputusan yang diambil oleh instansi pemerintah lainnya. ${ }^{12}$ Sedangkan Peter Leyland dan Terry Woods dengan tegas menyatakan bahwa kewenangan publik mempunyai 2 (dua) ciri utama, yakni: pertama, setiap keputusan yang dibuat oleh pejabat pemerintahan mempunyai kekuatan mengikat kepada seluruh anggota masyarakat, dalam arti harus dipatuhi oleh seluruh anggota masyarakat, dan kedua, setiap keputusan yang dibuat oleh pejabat pemerintah mempunyai fungsi publik atau melakukan pelayanan publik. ${ }^{13}$

Berkaitan dengan sifat wewenang tersebut, Safri Nugraha, dkk, mengemukakan bahwa sifat wewenang pemerintahan itu meliputi 3 (tiga) aspek, yakni selalu terikat pada suatu masa tertentu, selalu tunduk pada batas yang ditentukan dan pelaksanaan wewenang pemerintahan terikat pada hukum tertulis dan tidak tertulis. Lebih lanjut dijelaskan bahwa, sifat wewenang yang selalu terikat pada suatu masa tertentu ditentukan secara jelas dan tegas melalui suatu peraturan perundang-undangan. Lama berlakunya wewenang tersebut juga disebutkan dalam

6 Aminuddin Ilmar, Hukum Tata Pemerintahan, Jakarta: Kencana, 2014, hlm. 101.

7 Ibid., hlm. 102

8 Ridwan HR, Hukum Administrasi..., Loc. Cit.

9 Ibid

10 Nomensen Sinamo, Hukum Administrasi Negara, Jakarta: Jala Permata Aksara, 2010, hlm. 87.

11 Ibid., hlm. 89.

12 Prajudi Atmosudirdjo, Hukum Administrasi Negara, Jakarta: Ghalia Indonesia, 1981, hlm. 76.

13 Aminuddin Ilmar, Hukum Tata..., Op. Cit., hlm. 108. 
peraturan yang menjadi dasarnya. Sehingga bilamana wewenang pemerintahan itu digunakan dan tidak sesuai dengan sifat wewenang pemerintahan tersebut, maka tindakan atau perbuatan pemerintahan itu bisa dikatakan tidak sah atau batal demi hukum. ${ }^{14}$

Dalam negara hukum, wewenang pemerintahan itu berasal dari peraturan perundang-undangan yang berlaku. R.J.H.M. Huisman menyatakan pendapatnya bahwa organ pemerintahan tidak dapat menganggap bahwa ia memiliki sendiri wewenang pemerintahan. Kewenangan hanya diberikan oleh undang-undang. Pembuat undang-undang dapat memberikan wewenang pemerintahan tidak hanya kepada organ pemerintahan, tetapi juga terhadap para pegawai atau terhadap badan khusus atau bahkan terhadap badan hukum privat. $^{15}$

Secara teoretis, kewenangan yang bersumber dari peraturan perundang-undangan tersebut diperoleh melalui 3 (tiga) cara yaitu atribusi, delegasi dan mandat. Hal tersebut salah satunya dijelaskan oleh H.D. van Wijk yang memberikan defenisi ke setiap cara tersebut, yaitu: ${ }^{16}$

1. Atribusi adalah pemberian wewenang pemerintahan oleh pembuat undang-undang kepada organ pemerintahan;

2. Delegasi adalah pelimpahan wewenang pemerintahan dari satu organ kepada organ pemerintahan lainnya; dan

3. Mandat terjadi ketika organ pemerintahan mengizinkan kewenangannya dijalankan oleh organ lain atas namanya.

Berbeda dengan van Wijk, F.A.M. Stroink dan J.G. Steenbeek menyebutkan bahwa hanya ada 2 (dua) cara organ pemerintahan memperoleh wewenang, yaitu atribusi dan delegasi. Atribusi berkenaan dengan penyerahan wewenang baru, sedangkan delegasi menyangkut pelimpahan wewenang yang telah ada oleh organ yang telah memperoleh wewenang secara atributif kepada organ lain, jadi delegasi secara logis selalu didahului oleh atribusi. ${ }^{17}$

Menurut Indroharto, pada atribusi terjadi pemberian wewenang pemerintahan yang baru oleh suatu ketentuan dalam peraturan perundangundangan. Di sini dilahirkan atau diciptakan suatu wewenang baru. Lebih lanjut disebutkan bahwa legislator yang kompeten untuk memberikan atribusi wewenang pemerintahan itu dibedakan antara: ${ }^{18}$

a. Yang berkedudukan sebagai original legislator, di negara kita di tingkat pusat adalah Majelis Permusyawaratan Rakyat sebagai pembentuk konstitusi dan Dewan Perwakilan Rakyat bersama-sama Presiden sebagai yang melahirkan undang-undang dan di tingkat daerah adalah Dewan Perwakilan Rakyat Daerah dan Pemerintah Daerah yang melahirkan peraturan daerah;

b. Yang bertindak sebagai delegated legislator, seperti Presiden yang berdasar pada suatu ketentuan undang-undang mengeluarkan peraturan pemerintah di mana diciptakan wewenang-wewenang pemerintahan kepada badan atau jabatan tata usaha negara tertentu.

Dalam hal pelimpahan wewenang pemerintahan melalui delegasi, menurut Philipus M. Hadjon sebagaimana dikutip oleh Juniarso Ridwan dan Achmad Sodik Sudrajat, terdapat syarat-syarat yang harus dipenuhi sebagai berikut: ${ }^{19}$

1. Delegasi harus defenitif dan pemberi delegasi tidak dapat lagi menggunakan sendiri wewenang yang telah dilimpahkan itu;

2. Delegasi harus berdasarkan ketentuan peraturan perundang-undangan, artinya delegasi hanya dimungkinkan kalau ada ketentuan untuk itu dalam peraturan perundang-undangan;

3. Delegasi tidak kepada bawahan, artinya hubungan hierarki kepegawaian tidak diperkenankan adanya delegasi;

4. Kewajiban memberikan keterangan (penjelasan), artinya delegasi berwenang untuk meminta

14 Safri Nugraha, dkk, Hukum Administrasi Negara, Jakarta: Fakultas Hukum Universitas Indonesia, 2007, hlm. 31.

15 Ridwan HR, Hukum Administrasi..., Op. Cit., hlm. 103.

16 Ridwan HR, Hukum Administrasi..., Op. Cit., hlm. 104 - 105.

17 Ibid., hlm. 105.

18 Indroharto, Usaha Memahami Undang-Undang tentang Peradilan Tata Usaha Negara, Jakarta: Sinar Harapan, 1993, hlm. 83.

19 Juniarso Ridwan dan Achmad Sodik Sudrajat, Hukum Administrasi Negara dan Kebijakan Layanan Publik, Bandung: Nuansa, 2012, hlm. 139. 
penjelasan tentang pelaksanaan wewenang tersebut;

5. Peraturan kebijakan, artinya delegan memberikan instruksi (petunjuk) tentang penggunaan wewenang tersebut.

Berkenaan dengan mandat, Stroink dan Steenbeek menyatakan bahwa pada mandat tidak dibicarakan penyerahan wewenang, tidak pula pelimpahan wewenang. Dalam hal mandat tidak terjadi perubahan wewenang apapun. Yang ada hanyalah hubungan internal, sebagai contoh menteri dengan pegawai, menteri mempunyai kewenangan dan melimpahkan kepada pegawai untuk mengambil keputusan tertentu atas nama menteri, sementara secara yuridis wewenang dan tanggungjawab tetap berada pada organ kementerian. Pegawai memutuskan secara faktual, menteri secara yuridis. ${ }^{20}$

Jika dilihat dari sumber kewenangan yang terdiri dari atribusi, delegasi dan mandat, pemerintahan daerah memperoleh kewenangan melalui atribusi dan delegasi. Hal ini dapat dilihat dari materi muatan peraturan daerah sebagaimana diatur dalam Pasal 14 Undang-Undang Nomor 12 Tahun 2011 tentang Pembentukan Peraturan Perundang-undangan yang menyatakan bahwa "Materi muatan Peraturan Daerah Provinsi dan Peraturan Daerah Kabupaten/Kota berisi materi muatan dalam rangka penyelenggaraan otonomi daerah dan tugas pembantuan serta menampung kondisi khusus daerah dan/atau penjabaran lebih lanjut peraturan perundang-undangan yang lebih tinggi."

Berdasarkan ketentuan ini dapat disimpulkan bahwa pemerintahan daerah mempunyai kewenangan berdasarkan atribusi dalam rangka penyelenggaraan otonomi daerah dan tugas pembantuan dan secara delegasi sebagai penjabaran lebih lanjut peraturan perundang-undangan yang lebih tinggi.

\section{B.2. Kewenangan Atribusi Pemerintah Daerah}

Jika kita kemudian melihat kembali pendapat dari H.D. van Wijk yang menyatakan bahwa atribusi adalah pemberian wewenang pemerintahan oleh pembuat undang-undang kepada organ pemerintahan. Dalam hal pemberian wewenang kepada pemerintahan daerah, undang-undang yang menjadi dasar pemberian kewenangan kepada pemerintahan daerah secara atribusi adalah UndangUndang Nomor 23 Tahun 2014 tentang Pemerintahan Daerah.

Dalam ketentuan Pasal 9 disebutkan bahwa "Urusan pemerintahan terdiri atas urusan pemerintahan absolut, urusan pemerintahan konkuren dan urusan pemerintahan umum. Urusan pemerintahan absolut adalah urusan pemerintahan yang sepenuhnya menjadi kewenangan pemerintah pusat. Sedangkan urusan pemerintahan konkuren adalah urusan pemerintahan yang dibagi antara Pemerintah Pusat, dan Daerah Provinsi dan Daerah Kabupaten/Kota. Adapun urusan pemerintahan umum adalah urusan pemerintahan yang menjadi kewenangan presiden sebagai kepala pemerintahan.

Dari ketentuan ini dapat dilihat bahwa kewenangn pemerintahan daerah yang diperoleh secara atribusi adalah urusan pemerintahan konkuren. Yang pada Pasal 11 Undang-Undang Nomor 23 Tahun 2014 tentang Pemerintahan Daerah dibagi menjadi urusan pemerintahan wajib dan urusan pemerintahan pilihan. Urusan pemerintahan wajib terdiri atas urusan pemerintahan yang berkaitan dengan pelayanan dasar dan urusan pemerintahan yang tidak berkaitan dengan pelayanan dasar.

Rincian dari urusan pemerintahan wajib ini kemudian diatur dalam pada Pasal 12 UndangUndang Nomor 23 Tahun 2014 tentang Pemerintahan Daerah. Urusan pemerintahan wajib yang berkaitan dengan pelayanan dasar meliputi:

Pendidikan;

a. Kesehatan;

b. Pekerjaan umum dan penataan ruang;

c. Perumahan rakyat dan kawasan permukiman;

d. Ketenteraman, ketertiban umum dan pelindungan masyarakat; dan

e. Sosial.

Sedangkan urusan pemerintahan wajib yang tidak berkaitan dengan pelayanan dasar meliputi:

a. tenaga kerja;

b. pemberdayaan perempuan dan pelindungan

20 Ridwan HR, Hukum Administrasi..., Op. Cit., hlm. 106. 
anak;

c. pangan;

d. pertanahan;

e. lingkungan hidup;

f. administrasi kependudukan dan pencatatan sipil;

g. pemberdayaan masyarakat dan Desa;

h. pengendalian penduduk dan keluarga berencana;

i. perhubungan;

j. komunikasi dan informatika;

k. koperasi, usaha kecil, dan menengah; penanaman modal;

1. kepemudaan dan olah raga;

m. statistik;

n. persandian;

o. kebudayaan;

p. perpustakaan; dan

q. kearsipan.

Selain urusan pemerintahan wajib, pemerintahan daerah juga mempunyai kewenangan untuk melaksanakan urusan pemerintahan pilihan yang terdiri atas:

a. kelautan dan perikanan;

b. pariwisata;

c. pertanian;

d. kehutanan;

e. energi dan sumber daya mineral;

f. perdagangan;

g. perindustrian; dan

h. transmigrasi.

Urusan-urusan pemerintahan inilah yang kemudian menjadi kewenangan pemerintahan daerah secara atribusi. Dalam pelaksanaannya, tentu pemerintahan daerah harus mengeluarkan regulasi atau peraturan perundang-undangan sebagai aturan untuk melaksanakan kewenangan-kewenangan tersebut.

\section{B.3 Pelaksanaan Kewenangan Atribusi Pemerintah Daerah}

Dalam menjalankan pemerintahan di daerah, pemerintahan daerah mempunyai kewenangan untuk membentuk produk hukum di daerah. Jika melihat ketentuan dalam Pasal 7 Ayat (1) UndangUndang Nomor 12 Tahun 2011 tentang Pembentukan Peraturan Perundang-undangan yang mengatur tentang hierarki peraturan perundang-undangan, produk hukum daerah yang masuk hierarki adalah peraturan daerah provinsi dan peraturan daerah kabupaten/kota. Akan tetapi, dalam Pasal 8 Ayat (1) Undang-Undang Nomor 12 Tahun 2011 tentang Pembentukan Peraturan Perundang-undangan ada juga jenis peraturan perundang-undangan lain yang diakui seperti peraturan yang ditetapkan oleh gubernur dan bupati/walikota.

Ketentuan lebih lanjut mengenai produk hukum di daerah kemudian diatur dengan Peraturan Menteri Dalam Negeri Nomor 80 Tahun 2015 tentang Pembentukan Produk Hukum Daerah. Produk hukum daerah dalam Peraturan Menteri Dalam Negeri Nomor 80 Tahun 2015 tentang Pembentukan Produk Hukum Daerah ini disebutkan terdiri dari peraturan dan ketetapan. Produk hukum yang berbentuk peraturan terdiri atas:

a. Peraturan Daerah;

b. Peraturan Kepala Daerah;

c. Peraturan Bersama Kepala Daerah; dan

d. Peraturan Dewan Perwakilan Rakyat Daerah.

Sedangkan produk hukum daerah yang berbentuk ketetapan terdiri dari:

a. Keputusan Kepala Daerah;

b. Keputusan Dewan Perwakilan Rakyat Daerah;

c. Keputusan Pimpinan Dewan Perwakilan Rakyat Daerah; dan

d. Keputusan Badan Kehormatan Dewan Perwakilan Rakyat Daerah.

Dengan adanya ketentuan mengenai produk hukum daerah, menjadi pertanyaan dengan produk hukum apakah pemerintahan di daerah melaksanakan kewenangan atribusi yang diberikan berdasarkan Undang-Undang Nomor 23 Tahun 2014 tentang Pemerintahan Daerah. Apakah dengan peraturan daerah atau bisa dengan peraturan kepala daerah. 
Jika kita mengacu kepada materi muatan peraturan daerah yang diatur dalam Pasal 14 disebutkan bahwa "Materi muatan peraturan daerah provinsi dan peraturan daerah kabupaten/kota berisi materi muatan dalam rangka penyelenggaraan otonomi daerah dan tugas pembantuan serta menampung kondisi khusus daerah dan/atau penjabaran lebih lanjut peraturan perundang-undangan". Materi muatan peraturan daerah juga diatur dalam Pasal 236 Ayat (3) Undang-Undang Nomor 23 Tahun 2014 tentang Pemerintahan Daerah bahwa "Perda memuat materi muatan:

a. Penyelenggaraan otonomi daerah dan tugas pembantuan; dan

b. Penjabaran lebih lanjut ketentuan Peraturan Perundang-undangan yang lebih tinggi.

Ketentuan yang sama juga ditemukan pada Pasal 4 Peraturan Menteri Dalam Negeri Nomor 80 Tahun 2015 tentang Pembentukan Produk Hukum Daerah yang menyatakan bahwa "Perda memuat materi muatan:

a. Penyelenggaraan otonomi daerah dan tugas pembantuan; dan

b. Penjabaran lebih lanjut ketentuan peraturan perundang-undangan yang lebih tinggi."

Sedangkan materi muatan peraturan kepala daerah jika mengacu kepada ketentuan Pasal 246 Ayat (1) Undang-Undang Nomor 23 Tahun 2014 tentang Pemerintahan Daerah adalah untuk melaksanakan perda atau atas kuasa peraturan perundang-undangan.

Jika kita mengacu hanya pada materi muatan saja, maka untuk melaksanakan kewenangan atribusi yang diatur dalam Undang-Undang Nomor 23 Tahun 2014 tentang Pemerintahan Daerah adalah dengan peraturan daerah. Hal ini dapat kita telusuri dari beberapa ketentuan baik dalam Undang-Undang Nomor 12 Tahun 2011 tentang Pembentukan Peraturan Perundang-undangan maupun dalam Undang-Undang Nomor 23 Tahun 2014 tentang Pemerintahan Daerah.
Dalam ketentuan Pasal 9 Ayat (4) UndangUndang Nomor 23 Tahun 2014 tentang Pemerintahan Daerah disebutkan bahwa "Urusan Pemerintahan Konkuren yang diserahkan ke daerah menjadi dasar pelaksanaan otonomi daerah". Hal ini berarti bahwa urusan pemerintahan konkuren dilaksanakan pemerintahan daerah sebagai wujud dari pelaksanaan otonomi di daerah. Di mana daerah berhak untuk mengatur daerahnya sendiri.

Ketentuan ini kemudian dihubungkan dengan materi muatan dari peraturan daerah itu sendiri baik yang diatur pada Pasal 14 Undang-Undang Nomor 12 Tahun 2011 tentang Pembentukan Peraturan Perundang-undangan, Pasal 236 Ayat (3) UndangUndang Nomor 23 Tahun 2014 tentang Pemerintahan Daerah maupun Pasal 4 Peraturan Menteri Dalam Negeri Nomor 80 Tahun 2015 tentang Pembentukan Produk Hukum Daerah. Bahwa salah satu materi muatan peraturan daerah adalah dalam rangka penyelenggaraan otonomi daerah.

Dengan demikian, kewenangan atribusi pemerintahan daerah yang merupakan urusan pemerintahan konkuren yang bersifat wajib dan pilihan dilaksanakan oleh pemerintahan daerah dalam bentuk peraturan daerah. Situasi ini membuat peraturan daerah makin mempunyai kedudukan yang strategis dalam kehidupan berbangsa dan bernegara atau dengan kata lain peran peraturan daerah dalam melaksanakan urusan pemerintahan menjadi sangat besar. ${ }^{21}$

\section{B. Penutup}

Berdasarkan prinsip otonomi daerah, pemerintahan daerah mempunyai hak untuk mengurus sendiri urusan pemerintahan di daerah. Urusan-urusan pemerintahan ini kemudian dibagi menjadi urusan pemerintahan absolut, urusan pemerintahan konkuren dan urusan pemerintahan umum. Berdasarkan pembagian urusan ini, pemerintahan daerah berwenanag untuk melaksanakan urusan-urusan konkuren yang dibagi menjadi urusan pemerintah pusat, daerah provinsi dan daerah kabupaten/kota.

21 Eka NAM Sihombing, Perkembangan Kewenangan Pembatalan Peraturan Daerah dan Peraturan Kepala Daerah; Kajian Putusan Mahkamah Konstitusi Nomor 137/PUU-XIII/2015 dan Nomor 56/PUU-XIV/2016”, Jurnal Yudisial, Vol. 10 No. 2 Agustus 2017, hlm. $226-227$. 
Pelaksanaan otonomi daerah ini tentu harus dibuat dengan peraturan sebagai acuan dalam pelaksanaan kewenangan pemerintahan daerah. Untuk melaksanakan hal tersebut berdasarkan ketentuan yang ada harus dibuat dalam bentuk peraturan daerah. Hal ini dapat dilihat dari materi muatan peraturan daerah yang salah satunya adalah dalam rangka penyelenggaraan otonomi daerah. Sehingga untuk melaksanakan kewenangan atribusi yang diatur dalam Undang-Undang Nomor 23 Tahun 2014 tentang Pemerintahan Daerah, pemerintahan daerah harus menuangkannya dalam bentuk peraturan daerah.

Berdasarkan hal tersebut dapat disarankan agar pengaturan mengenai pelaksanan kewenangan atribusi atau urusan konkuren harus diatur dengan peraturan daerah bukan dengan peraturan kepala daerah. Karena hal tersebut akan mengakibatkan peraturan yang dibentuk bertentangan dengan asas materi muatan yang tepat dalam pembentukan peraturan perundang-undangan.

\section{Daftar Pustaka}

\section{Buku}

Aminuddin Ilmar, Hukum Tata Pemerintahan, Jakarta: Kencana, 2014.

Bagir Manan, Hubungan antara Pusat dan Daerah Menurut UUD 1945, Jakarta: Pustaka Sinar Harapan, 1994.

Indroharto, Usaha Memahami Undang-Undang tentang Peradilan Tata Usaha Negara, Jakarta: Sinar Harapan, 1993.

Juniarso Ridwan dan Achmad Sodik Sudrajat, Hukum Administrasi Negara dan Kebijakan Layanan Publik, Bandung: Nuansa, 2012.

Ni'matul Huda, Hukum Pemerintahan Daerah, Jakarta: Nusamedia, 2009.

Nomensen Sinamo, Hukum Administrasi Negara, Jakarta: Jala Permata Aksara, 2010.

Prajudi Atmosudirdjo, Hukum Administrasi Negara, Jakarta: Ghalia Indonesia, 1981.

Ridwan HR, Hukum Administrasi Negara, Jakarta:
Rajawali Pers, 2006.

Safri Nugraha, dkk, Hukum Administrasi Negara, Jakarta: Fakultas Hukum Universitas Indonesia, 2007.

Victor M. Situmorang, Hukum Administrasi Pemerintahan di Daerah, Jakarta: Sinar Grafika, 1994.

\section{Jurnal dan Disertasi}

Eka NAM Sihombing, "Perkembangan Kewenangan Pembatalan Peraturan Daerah dan Peraturan Kepala Daerah; Kajian Putusan Mahkamah Konstitusi Nomor 137/PUU-XIII/2015 dan Nomor 56/PUU-XIV/2016", Jurnal Yudisial, Vol. 10 No. 2 Agustus 2017.

Nukhtoh Arfawie Kurde, Peranan Desentralisasi dan Otonomi Daerah dalam Penguatan Integrasi Negara Kesatuan Republik Indonesia, Yogyakarta, Program Pasca Sarjana FH UII, 2006.

\section{Peraturan Perundang-undangan}

Undang-Undang Nomor 12 Tahun 2011 tentang Pembentukan Peraturan Perundang-undangan.

Undang-Undang Nomor 23 Tahun 2014 tentang Pemerintahan Daerah.

Peraturan Menteri Dalam Negeri Nomor 80 Tahun 2015 tentang Pembentukan Produk Hukum Daerah. 